\title{
The effects of hypersalinity on the growth and skeletal anomalies of juvenile Cape stumpnose, Rhabdosargus holubi (Sparidae)
}

\author{
Yanasivan Kisten ${ }^{1,2}$, Nadine A. Strydom ${ }^{2}$, Renzo Perissinotto ${ }^{1}$ \\ ${ }^{1}$ DST/NRF Research Chair in Shallow Water Ecosystems, Nelson Mandela University, Ocean Science Campus, \\ P.O. Box 77000, Port Elizabeth 6031, South Africa. \\ (YK) (Corresponding author) E-mail: yanasivan@gmail.com. ORCID iD: http://orcid.org/0000-0001-5468-0230 \\ (RP) E-mail: renzo.perissinotto@mandela.ac.za. ORCID iD: http://orcid.org/0000-0002-9224-3573 \\ ${ }^{2}$ Department of Zoology, Nelson Mandela University, Summerstrand Campus South, P.O. Box 77000, Port Elizabeth 6031, \\ South Africa. \\ (NAS) E-mail: nadine.strydom@mandela.ac.za. ORCID iD: http://orcid.org/0000-0003-4292-8678
}

\begin{abstract}
Summary: Estuarine organisms are exposed to hypersaline conditions for prolonged periods during drought conditions and under severely restricted river flow resulting from freshwater abstraction and impoundments. Consequently, marine estuarine-dependent fish such as Rhabdosargus holubi may be subjected to extreme conditions, such as hypersalinity prevailing for long periods ( $>2$ months). Hypersalinity may impact the energetic demands of fish due to osmoregulation leading to compromised growth. This study assessed the impact of high salinity on the growth and skeletal development of $R$. holubi juveniles. Skeletons of juveniles grown at different salinities in the wild and in aquaria were analysed for anomalies. The impact of hypersaline conditions on juvenile $R$. holubi growth was also determined in aquaria. Aquarium experiments indicated that hypersalinity of 50 did not significantly impact growth rates over two months. Overall, anomalies were rare and vertebral-related anomalies specifically did not differ significantly between salinities. However, fin rays were significantly impacted in fish growing at higher salinities in the wild. It was concluded that the strong osmoregulatory ability of $R$. holubi offers protection against hypersalinity affecting internal structures, but external structures may remain vulnerable. As such, from a locomotory standpoint, $R$. holubi may be vulnerable to long periods of exposure to hypersaline conditions.
\end{abstract}

Keywords: fish physiology; growth anomalies; hypersalinity; skeletal development.

Efecto de la hipersalinidad sobre el crecimiento y anomalías esqueléticas en juveniles de sargo del Cabo, Rhabdosargus holubi (Sparidae)

Resumen: Los organismos que habitan en estuarios están expuestos a condiciones de hipersalinidad durante períodos de sequía y en momentos en los que el aporte de agua fluvial se reduce de forma importante por substracción de aguas o presencia de embalses. Así, los peces marinos que dependen de los estuarios, como Rhabdosargus holubi, pueden estar expuestos a condiciones extremas, tales como una hipersalinidad de larga duración ( $>2$ meses). La hipersalinidad puede afectar los requerimientos energéticos de los peces debido al proceso de osmoregulación y comprometer el correcto crecimiento del individuo. Este estudio investigó el impacto de altas salinidades sobre el crecimiento y el desarrollo esquelético en juveniles de Rhabdosargus holubi. Se analizó el esqueleto de juveniles crecidos en diferentes salinidades, tanto en el medio natural como en acuarios, para detectar la presencia de anomalías esqueléticas. Además, se estudió el impacto de condiciones de hipersalinidad en acuarios, sobre el crecimiento de juveniles de Rhabdosargus holubi. Los experimentos en acuario indicaron que una exposición de 2 meses a hipersalinidad de 50 no afectaron significativamente las tasas de crecimiento. La presencia de anomalías esqueléticas fue escasa y en concreto, las relativas a las vértebras fueron similares entre los grupos expuestos a las diferentes salinidades. Sin embargo, si se detectó un impacto significativo sobre el desarrollo de los radios de las aletas en los peces expuestos a altas salinidades en el medio natural. En conclusión, los resultados del estudio sugieren que la fuerte capacidad osmoreguladora de $R$. holubi le protege contra los efectos de la hipersalinidad sobre las estructuras internas, pero no sobre las estructuras externas, que permanecerían vulnerables a estas condiciones. Así, desde el punto de vista de la locomoción, $R$. holubi sería vulnerable a una exposición prolongada a condiciones de hipersalinidad.

Palabras clave: fisiología de peces; anomalías de crecimiento; hipersalinidad; desarrollo esquelético.

Citation/Como citar este artículo: Kisten Y., Strydom N.A., Perissinotto R. 2019. The effects of hypersalinity on the growth and skeletal anomalies of juvenile Cape stumpnose, Rhabdosargus holubi (Sparidae). Sci. Mar. 83(1): 61-68. https:// doi.org/10.3989/scimar.04859.24A

Editor: E. Mañanós.

Received: September 12, 2018. Accepted: January 29, 2019. Published: March 6, 2019.

Copyright: (C) 2019 CSIC. This is an open-access article distributed under the terms of the Creative Commons Attribution 4.0 International (CC BY 4.0) License. 


\section{INTRODUCTION}

Estuaries can be areas of rapid environmental change as physico-chemical variables such as salinity and temperature may vary within tidal scales, localized seasonal weather patterns and inter-annual climatic shifts (Wallace et al. 1984, James et al. 2013, Potts et al. 2015). This is notwithstanding the further variability caused by anthropogenic drivers such as freshwater abstraction, impoundments, pollution and climate change (Koehn et al. 2011, James et al. 2013, Adams et al. 2016). Hypersaline conditions arise when salinity exceeds that of seawater through excess evaporation exceeding freshwater inflow during droughts, or through physical modifications to the estuary, with the biogeochemistry of the catchment area also playing a role (Potter et al. 2010, Gonzalez 2012, Strydom 2015). For example, the intermittently open Gqutywa Estuary in the Eastern Cape, South Africa, becomes hypersaline at times due to its closed nature and catchment geochemistry (Teske and Wooldridge 2001, Strydom et al. 2003).

Hypersaline conditions may result in several physiological challenges to fish species (Brauner et al. 2012). The difference in osmotic pressure between the internal structures and the external environment of teleost fish, such as the common bream Rhabdosargus holubi (family Sparidae), results in a loss of water, which must be mitigated by drinking (Brauner et al. 2012). This results in salt absorption across the gut, which must be excreted to prevent elevated internal levels and osmotic disturbances (Bœuf and Payan 2001, Brauner et al. 2012). A generalized trend for the impact of osmoregulation on fish respiration and growth is unclear (Bœuf and Payan 2001, Gonzalez 2012). Previous studies have shown that the impact of osmoregulation on the energy expenditure of fish may be higher than $50 \%$ or lower than $10 \%$, varying considerably between species (Bœuf and Payan 2001, Gonzalez 2012, Ern et al. 2014). Thus, it is possible that changing salinity may have species-specific effects on the physiology of fish (Bœuf and Payan 2001). This may be especially true for euryhaline species such as $R$. holubi, which is an estuarine-dependent marine species that is endemic and common in South African estuaries, where salinities may vary considerably (Blaber 1973a, Whitfield 1998, Whitfield et al. 2006).

Hypersalinity can cause osmotic stress in organisms living in estuaries, resulting in potentially lower growth rates, skeletal deformities and mortality at extreme levels (Bœuf and Payan 2001, Gonzalez 2012, Boglione et al. 2013b). These kinds of skeletal deformities are prevalent in aquaculture conditions, where even small changes to salinity may impact on the survival and growth of larvae and juvenile fish (Boglione et al. 2013a, b). Skeletal anomalies usually occur during skeletogenesis, which persists into the juvenile phase, but skeletal and fin anomalies can also occur in smaller-sized juveniles (Boglione et al. 2009, 2013b, 2014).

Larvae and small juveniles of $R$. holubi migrate into estuaries at a size of less than $30 \mathrm{~mm}$ and grow for about a year and a half to over $140 \mathrm{~mm}$ before migrating back to the ocean to spawn (Whitfield 1998, Götz and Cowley 2013). Juvenile $R$. holubi are usually highly resident, preferring to stay within habitats such as Zostera capensis seagrass beds within the estuary (Edworthy and Strydom 2016, Grant et al. 2017, Muller and Strydom 2017). R. holubi is a strong osmoregulator able to maintain its internal osmotic environment up to 65 (Blaber 1973a, 1974b). Previous investigations of $R$. holubi tolerance to high salinity carried out in the laboratory have indicated a maximum threshold of 70 after a 16-hour exposure (Blaber 1973b). However, $R$. holubi individuals have been recorded alive in the wild at salinity levels up to 90 , and it is one of the few species capable of surviving under intense drought conditions (Whitfield 1998, Whitfield et al. 2006). This makes it a euryhaline species able to tolerate a large variation in salinity, as opposed to stenohaline species that can tolerate only minor changes (Whitfield et al. 1981, Brauner et al. 2012, Kültz 2015). Spinal and fin deformities can still be observed in euryhaline fishes such as Atherina lagunae due to the potential combined effects of temperature, pollution, and oxygen deficiency (Ayed et al. 2008). Despite the high tolerances reported in the literature, the physiological effects of $R$. holubi living under high salinities for long periods are unknown and there are still potential effects to external structures, such as fin abrasions or swimbladder anomalies due to buoyancy changes and bacterial infections (Latremouille 2003, Boglione et al. 2013a, b). This study aims to assess the impact of natural in situ and laboratory-manipulated hypersaline conditions on the growth and frequency of skeletal anomalies of juvenile $R$. holubi.

\section{MATERIALS AND METHODS}

\section{Field collections}

To assess the skeletal descriptors to identify anomalies in $R$. holubi juveniles growing at different salinities, wild specimens were collected from the lower reaches of the naturally hypersaline Gqutywa $\left(33^{\circ} 21^{\prime} 45^{\prime \prime} \mathrm{S} ; 27^{\circ} 21^{\prime} 31^{\prime \prime} \mathrm{E}\right)$ and the marine-dominated Swartkops (33 $\left.51^{\prime} 54^{\prime \prime} \mathrm{S}, 25^{\circ} 38^{\prime} 00^{\prime \prime} \mathrm{E}\right)$ estuaries during March 2015. At least 50 specimens were collected from each site using a $30 \times 1.5-\mathrm{m}$ seine net of $10 \mathrm{~mm}$ bar mesh size. Specimens were fixed in $10 \%$ formalin and transported to Nelson Mandela University for skeletal descriptor analysis. A YSI 6600 multiparameter probe was used to measure the environmental variables present at the time of sampling.

The Swartkops Estuary is categorized as permanently open while the Gqutywa Estuary is categorized as temporarily open/closed (Whitfield and Baliwe 2013). The Swartkops has been shown to be marinedominated at the lower reaches with comparatively low freshwater inflow (Baird et al. 1986, Pattrick and Strydom 2014, Strydom 2015), with salinities ranging from 24.61 to 33.44 in the autumn sampling season. At the time of sampling, the following values for the key environmental variables were recorded at the Swartkops 
Estuary: temperature, $23.42^{\circ} \mathrm{C}$; salinity, $31.32 ; \mathrm{pH}$, 7.51; turbidity, $13.2 \mathrm{NTU}$; oxygen saturation, $100 \%$; conductivity, $48.46 \mu \mathrm{S} \mathrm{cm}^{-1}$; and total dissolved solids, $31.51 \mathrm{mg} \mathrm{l}^{-1}$. The Gqutywa Estuary is categorized as hypersaline, with salinities previously ranging from 35.66 to 43.19 during the period 1998-1999 (Strydom et al. 2003). At the time of sampling, the following values were recorded for the environmental variables at the Gqutywa: temperature, $24.54^{\circ} \mathrm{C}$; salinity, 39.55; $\mathrm{pH}$, 7.76; turbidity, 2.4 NTU; oxygen, $100 \%$; conductivity, $58.77 \mu \mathrm{S} \mathrm{cm}^{-1}$; and total dissolved solids, $38.77 \mathrm{mg} \mathrm{l}^{-1}$. The climate in the sampling region is categorized as warm temperate, with rainfall peaking bimodally in winter and spring (Strydom et al. 2003, Pattrick and Strydom 2014).

\section{Aquarium rearing and fish growth}

To assess the skeletal descriptors of $R$. holubi juveniles grown at different salinities in the laboratory, specimens $(n=589$ total) were collected at the Swartkops Estuary between April and May 2017 using a $30 \times 1.5-\mathrm{m}$ seine net of $10 \mathrm{~mm}$ bar mesh size and transported to the aquarium laboratory at Nelson Mandela University. The specimens were then distributed among 12 glass 200-L capacity tanks for laboratory acclimatization. Each tank contained mechanical floss outflow filters, a Bubble Magus protein skimmer and a Matrix Biofilter treated with Seachem Stability. For at least two weeks prior to experiments, the specimens were acclimatized to standard laboratory conditions of $19^{\circ} \mathrm{C}$ to $21^{\circ} \mathrm{C}$ (measured with aquarium thermometers) and 29 to 31 salinity (measured with an ATC refractometer) obtained using reverse osmosis water with Blue Treasure Marine Salt. Fish were fed daily to satiation with Omega One marine flakes (43\% protein, $11 \%$ fat and $2 \%$ fibre). A RED SEA Marine Lab aquarium kit was used to test $\mathrm{pH}$ (maintained at 8.0-8.4) and concentrations of ammonia (maintained at $<0.2 \mathrm{ppm}$ ), nitrite (maintained at $<0.05 \mathrm{ppm}$ ), nitrate (maintained at $<20 \mathrm{ppm}$ ) and phosphate (maintained at $<0.2 \mathrm{ppm}$ ) on a weekly basis. Mechanical filters and $10 \%$ water were also changed weekly.

For the salinity experiments, six aquaria were used with 20 fish of $46.48 \pm 7.2 \mathrm{~mm}$ (mean \pm SD) length (120 total). Three tanks served as controls maintained at standard laboratory conditions which mimicked those of the sampling site (salinity $=29.15 \pm 0.55$, mean \pm SD) while three tanks were maintained at a higher salinity of $49.9 \pm 1.16($ mean $\pm \mathrm{SD})$ for the hypersaline treatment, which was higher than levels recorded in the Gqutywa. The hypersaline exposure salinity level ( 50) was chosen based on a combination of pilot observations in the laboratory and to closer reflect salinities seen in the Gqutywa Estuary, which is generally considered a hypersaline sampling station for ecological studies. Salinity in hypersaline treatment tanks was gradually raised from standard conditions over three weeks via daily $\sim 5 \%$ water changes of 50-60 salinity, and was then left at $\sim 50$ for the remainder of the study. Fish were measured for total length weekly for nine consecutive weeks using measuring boards, while environmental variables were measured with a YSI 6600 multiparameter probe. After 9 weeks, the fish began exhibiting signs of fin erosion, at which point the growth experiment was stopped. At the end of the exposure, the fish were removed and fixed in 10\% formalin and kept until processing for skeletal descriptor analysis.

\section{Skeletal descriptor analysis}

To assess skeletal descriptors and identify anomalies, the fish tissues were cleared, and bone and cartilage were stained using methods described by Taylor and Van Dyke (1985). In summary, the fish specimens were descaled and deskinned with a scalpel before transfer to $95 \%$ ethanol for dehydration for 24 hours. They were then transferred to Alcian Blue cartilage stain for 8 hours and transferred to saturated sodium borate solution for a six-hour neutralization. The cartilage stain solution consisted of $70 \%$ of $95 \%$ ethanol, $30 \%$ acetic acid and $\sim 2 \mathrm{mg}$ Alcian Blue per litre of medium. The bones were also stained using Alizarin Red (mixed until dark purple) in $1 \%$ potassium hydroxide solution. Specimens were then transferred to a digestion solution containing diluted saturated sodium borate solution and porcine trypsin powder of roughly five teaspoons per two litres of medium. The fish were left to digest until the tissues were clear enough for analysis. Digestion solutions were changed every week until complete, and digestion times varied between fish sizes. The fish skeletons were observed on both sides under a stereomicroscope (BestScope, 40-50× magnification depending on size) and analysed for the presence of anomalies considered in Table 1 and adapted from Boglione et al. (2001). The anomalies considered in this analysis were described in a review by Boglione et al. (2013b), and included severe deformities such as shorter-than-usual fin rays, supernumerary fin rays, lordosis (downward concave curvature), kyphosis (upward concave curvature) and vertebral fusions. The most abundant types of anomalies were reduced fin rays and slight malformations in neural or haemal spines of vertebrae.

\section{Statistical analyses}

One-way ANOVA indicated that $R$. holubi specimen length (mean $46.48 \mathrm{~mm} \pm 7.23 \mathrm{SD}$ ) did not differ between tanks at the start of the growth experiment $(n=20, F=0.204, p=0.96)$. A repeated-measures ANOVA was used to determine the difference in length between control (salinity $~ 30$ ) and hypersaline (salinity 50) treatments over time. Mauchly's test of sphericity was violated $(\mathrm{W}=0.03, \mathrm{p}<0.05)$, so the Greenhouse Geisser value was applied $(\varepsilon=0.52)$.

The average number of vertebra-related anomalies per fish and the average number of fin ray-related anomalies per fish were compared between salinity treatments for the wild-caught and aquarium-grown fish using a Mann-Whitney $U$ test since parametric test assumptions were violated. Mann-Whitney U tests were also used to compare skeletal anomaly frequencies i.e. the number fish per anomaly type between fish 
Table 1. - List of skeletal anomalies considered for analysis of Rhabdosargus holubi juveniles grown in different conditions, adapted from Boglione et al. (2001).

\begin{tabular}{|c|c|c|}
\hline Category of anomaly & Region of skeleton & Type of anomaly \\
\hline Vertebral & $\begin{array}{l}\text { Cephalic vertebrae } \\
\text { Pre-haemal vertebrae } \\
\text { Haemal vertebrae } \\
\text { Caudal vertebrae }\end{array}$ & $\begin{array}{l}\text { Lordosis (upward concave curvature of the spine; Fig } 2 \mathrm{~B} \text { ) } \\
\text { Kyphosis (downward convex curvature of the spine) } \\
\text { Partial vertebrae fusion } \\
\text { Total vertebrae fusion } \\
\text { Vertebral anomaly (shape, ossification, ridges, reduction/elongation) } \\
\text { Anomalous neural arch/spine } \\
\text { Anomalous haemal arch/spine } \\
\text { Anomalous rib } \\
\text { Anomalous hypural } \\
\text { Anomalous parahypural } \\
\text { Anomalous epural }\end{array}$ \\
\hline Fin & $\begin{array}{l}\text { Pectoral fin } \\
\text { Pelvic fin } \\
\text { Anal fin } \\
\text { Caudal Fin } \\
\text { Dorsal Fin }\end{array}$ & $\begin{array}{l}\text { Anomalous rays } \\
\text { Anomalous pterygophores }\end{array}$ \\
\hline Miscellaneous & & $\begin{array}{l}\text { Cephalic anomalies (dental/maxillary/premaxillary/opercular plates) } \\
\text { Swim bladder anomaly }\end{array}$ \\
\hline
\end{tabular}

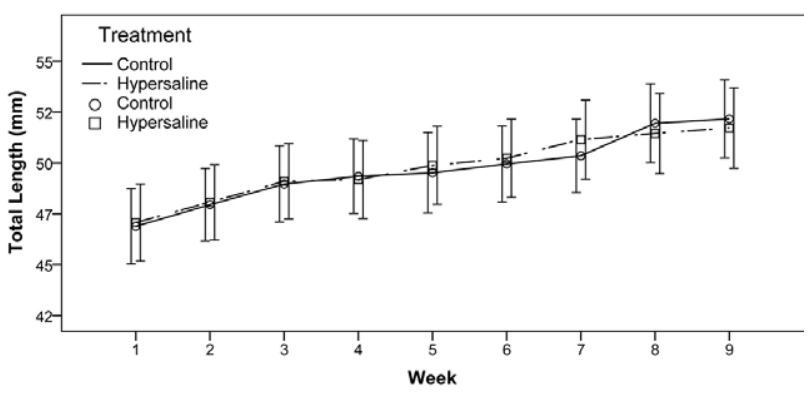

Fig. 1. - Mean total length $(\mathrm{mm} \pm \mathrm{SD})$ of Rhabdosargus holubi juveniles grown under control $(\sim 30)$ and hypersaline $(\sim 50)$ treatments for 9 weeks.

collected in the Swartkops and Gqutywa estuaries, as well as between control and hypersaline treatments. Data were analysed and compared in total and according to two size classes for the field data $(38-60 \mathrm{~mm}$ and 61-104 mm). Statistics were performed in SPSS V 21.0.

\section{RESULTS}

\section{Fish growth versus salinity in the aquarium}

Repeated-measures ANOVA indicated that $R$. holubi length increased weekly $(\mathrm{F}=223.48, \mathrm{p}<0.005$, Fig. 1) and that the interaction between time and treatment was significant for the within-subject effects $(\mathrm{F}=2.93$, $\mathrm{p}=0.02)$. However, overall length did not differ between control and hypersaline treatments $(\mathrm{F}=0.003$, $\mathrm{p}=0.96)$.

\section{Skeletal anomalies in wild-caught fish}

Standard lengths of wild-caught individuals ranged from 40 to $104 \mathrm{~mm}$. Of the 44 anomalies considered, 12 types were present in wild-caught individuals. Twentyone of a hundred individuals were malformed, the majority of them from the naturally hypersaline Gqutywa Estuary samples. No severe anomalies such as vertebral kyphosis, lordosis or fusions were detected. The average number of anomalies found was higher in the Gqutywa Estuary samples, especially for fin-related samples, as these were mostly absent in Swartkops Estuary samples (Table 2, Fig. 2). Fin-related anomalies in Gqutywa and Swartkops estuary samples included mostly dorsal and caudal fin breaks and erosions (Fig. 2 ). Vertebra-related anomalies consisted mainly of minor neural spine anomalies. Total frequency (number of individuals) with each of the 44 anomalies also differed between the Gqutywa and the Swartkops estuaries, with higher incidences of fin-related anomalies in the Gqutywa Estuary (Mann-Whitney $\mathrm{U}=336, \mathrm{Z}=-12.42$, $\mathrm{p}<0.005)$. Anomalies were only present in the smaller size class in the Swartkops Estuary, while there was no difference between size classes in the Gqutywa Estuary (Mann-Whitney $\mathrm{U}=906.5, \mathrm{Z}=-0.21, \mathrm{p}=0.83$ ).

\section{Skeletal anomalies in fish reared at different salinities}

Most individuals in both the 30 and 50 salinity treatments grown in aquaria exhibited no skeletal anomalies. Of the 120 individuals surveyed, 18 were

Table 2. - Comparison of the mean $( \pm \mathrm{SD})$ number of total, vertebral-related and fin-related anomalies found in juvenile Rhabdosargus holubi from the Swartkops and Gqutywa estuaries $(n=50$ total each) and grown in aquaria at a control 30 and hypersaline 50 salinity treatment ( $\mathrm{n}=$ 60 total each). For wild-caught fish, size class 1 included individuals of 38 to $60 \mathrm{~mm}$ total length, while size class 2 included individuals of 61 to $104 \mathrm{~mm}$ total length. The samples from the Swartkops Estuary did not contain enough fin anomalies for specific size class comparisons. An asterisk $(*)$ shows statistical differences $(\mathrm{p}<0.05)$ between treatments of a Mann-Whitney $U$ test.

\begin{tabular}{|c|c|c|c|c|c|c|c|c|c|}
\hline Anomalies & Total & $\begin{array}{c}\text { Total } \\
\text { Vertebral }\end{array}$ & Fin & Total & $\begin{array}{c}\text { Class } 1 \\
\text { Vertebral }\end{array}$ & Fin & Total & $\begin{array}{c}\text { Class } 2 \\
\text { Vertebral }\end{array}$ & Fin \\
\hline Swartkops (wild) & $0.06 \pm 0.2 *$ & $0.04 \pm 0.20$ & $0.02 \pm 0.14 *$ & $0.08 \pm 0.27 *$ & $0.05 \pm 0.23 *$ & $0.03 \pm 0.16$ & $(-)^{*}$ & $(-)^{*}$ & $(-)$ \\
\hline Gqutywa (wild) & $0.4 \pm 0.24 *$ & $0.06 \pm 0.24$ & $0.22 \pm 0.51 *$ & $0.43 \pm 0.79 *$ & $0.24 \pm 0.53 *$ & $0.19 \pm 0.5$ & $0.66 \pm 0.47 *$ & $0.14 \pm 0.34 *$ & $0.4 \pm 0.55$ \\
\hline Control (30 salinity) & $0.13 \pm 0.34$ & $0.12 \pm 0.32$ & $0.01 \pm 1.3$ & $(-)$ & $(-)$ & $(-)$ & $(-)$ & $(-)$ & $(-)$ \\
\hline Hypersaline (50 salinity) & $0.17 \pm 0.38$ & $0.1 \pm 0.3$ & $0.07 \pm 0.25$ & $(-)$ & $(-)$ & $(-)$ & $(-)$ & $(-)$ & $(-)$ \\
\hline
\end{tabular}




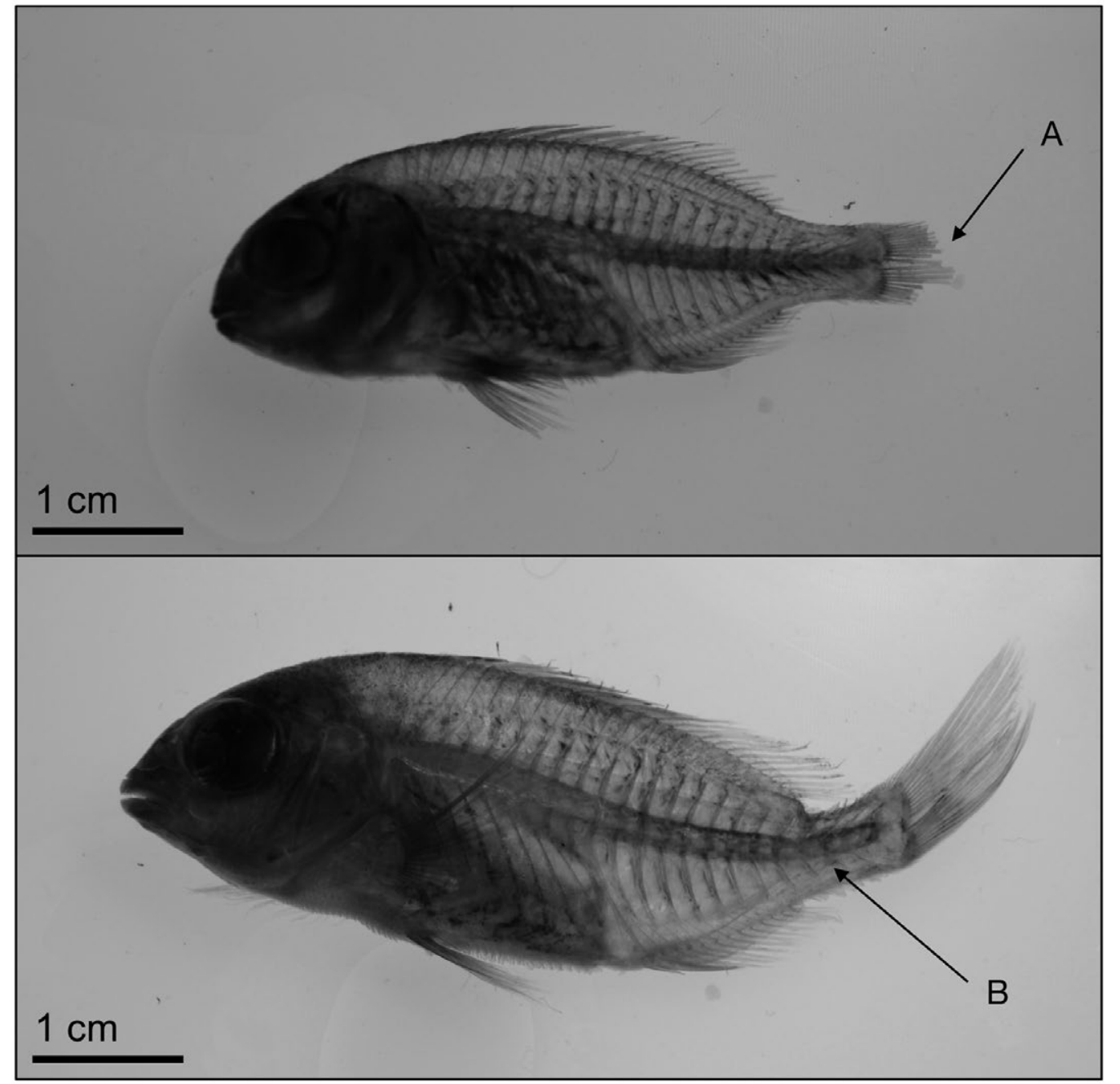

Fig. 2. - Cleared and stained skeletons of juvenile Rhabdosargus holubi indicating examples of caudal fin ray anomalies (A), and caudal vertebrae lordosis (B) in specimens from the Swartkops Estuary living in hypersaline conditions of 50 in aquaria for 10 weeks.

anomalous, the majority exhibiting lordosis in the haemal or caudal regions or an eroded caudal fin ray (Fig. 2). There was no significant difference between the number of vertebra-related or fin-related anomalies between the control and hypersaline groups in the laboratory (Table 2). Total frequency of each anomaly tested $(n=44)$ differed between control and hypersaline treatments, with higher incidences of fin-related anomalies being found in the hypersaline treatment (Mann-Whitney U=1294.5, Z=-9.98, p<0.005).

\section{DISCUSSION}

Hypersaline conditions may potentially place a significant impact on the physiology of estuarine fish during drought conditions or freshwater impoundments, thus affecting their ecology (Bøuf and Payan 2001, Harrison and Whitfield 2006, Gonzalez 2012). This study was aimed at assessing the growth and skeletal anomalies of $R$. holubi juveniles growing at different salinities in situ and in the laboratory using clearing and staining techniques (Taylor and Van Dyke 1985) to determine the impact of hypersaline conditions over the long term. It was found that hypersaline conditions with a salinity of 50 for two months did not significantly impact the growth of $R$. holubi for most of the duration of the experiment, compared with control samples kept at salinity levels around 30, similar to those in their natural habitat. It was found that skeletal anomalies were rare, occurring in less than $20 \%$ of all skeletal samples surveyed. The highest incidences of anomalies were found in $R$. holubi juveniles from the naturally hypersaline Gqutywa Estuary, particularly affecting their fin rays. Conversely, vertebra-related anomalies, i.e. those in vertebra, spines, arches and crania, did not differ significantly between treatments.

The degree of metabolic activity due to osmoregulation varies widely in the literature, ranging from less than $10 \%$ to more than $50 \%$ of the total energy cost (Bœuf and Payan 2001, Gonzalez 2012, Ern et al. 2014). Generally, when fish are gradually acclimated, tolerance to hypersaline conditions increases and may also lead to lower metabolic costs (Gonzalez et al. 2005, Whitfield et al. 2006, Gonzalez 2012). Fish may respond to increased solute concentrations by increasing salt excretion rates and reducing gill epithelial permeability (Gonzalez et al. 2005, Gonzalez 2012). Growth rates in many fish species, such as the marine 
estuarine-opportunist Mugil cephalus, are shown to decrease at high salinities due to the compromise of reducing oxygen intake while decreasing gill permeability to prevent the absorption of solutes (Bœuf and Payan 2001). Additionally, many other metabolic pathways are impacted during changing salinity, including changing gill ventilation, acid-base regulation and hormonal regulation (Claireaux and Lagardère 1999, Deane and Woo 2009, Ern et al. 2014). In some species, growth may even increase at high salinities. In the euryhaline milkfish Chanos chanos for example, swimming activity declines at a salinity of 55 compared with 35 , leading to a higher growth rate over a period of four weeks (Swanson 1998). Thus, the lack of effect of salinity on growth may be due to the offset of osmoregulatory metabolic demands by a reduction in movement. This was seen anecdotally in the laboratory and also evidenced by a decrease in respiration rates at high salinities found in pilot studies (Kisten 2018). In an ecological context, these results show why $R$. holubi is able to tolerate and proliferate under high-salinity conditions (Whitfield et al. 2006) and can be the most populous marine estuarine-dependant species in intermittently open estuaries during the closed mouth state (James et al. 2007, Whitfield et al. 2017).

If fish are able to manage the solute levels in their internal environment, it follows that damage to, or malformations of, internal structures such as the skeleton may be minimized (Gonzalez 2012, Boglione et al. $2013 b$ ). The ability of the euryhaline $R$. holubi to maintain its internal osmotic environment near isosmotic levels at salinities up to 65 (Blaber 1974b) may explain the lack of incidence and difference between treatments of vertebral anomalies obtained in this study. Further, skeletal anomalies tend to be more pronounced if they develop during earlier stages in the life cycle (Boglione et al. 2001, 2013b, Alarape et al. 2015). This may explain the low incidence of skeletal anomalies in juveniles, especially in the aquarium samples, as the early preflexion larval stages occur in the relatively stable marine environment. This may also explain why wild hypersaline juveniles exhibited anomalies while aquariums samples did not, as individuals in the Gqutywa Estuary may have been exposed to high salinities and other factors at a younger age and for a longer period. However, due to a combination of pollution and other environmental variables, skeletal anomalies such as those observed in Atherina lagunae (Ayed et al. 2008) can also occur in early juvenile euryhaline fish species. Lordosis (abnormal upward concave curvature) and vertebral spine/arch malformations were some of the most common vertebral-related anomalies present in anomalous samples. Lordosis of the haemal and caudal regions can be attributed to high water current, forced swimming and high temperatures (Divanach et al. 1996, 1997, Boglione et al. 2013b), which may explain why smaller individuals in aquaria exhibited this in both salinity treatments used in this study, as the other variables were kept constant. Anomalies affecting neural and haemal spines and arches are considered less severe and less likely to impact the performance of fish (Boglione et al. 2013b), especially at the low levels observed in this study. These anomalies may also be linked to other environmental variables, and particularly a nutrient-deficient diet rather than environmental salinity (Divanach et al. 1996, Izquierdo et al. 2010, Boglione et al. 2013b). As such it is difficult to conclude that a hypersaline environment may have any effect on the internal structures of $R$. holubi at the salinity levels and exposure durations tested in this study, particularly since other factors such as temperature were kept constant in the laboratory but would vary considerably in the wild.

Fin rays were the most significantly affected structures found in hypersaline conditions both in situ in the Gqutywa Estuary and in the laboratory at a salinity of 50 (Fig. 2). Fin ray anomalies are common in many species in both the wild and in aquaculture conditions (Divanach et al. 1996, Boglione et al. 2013b). However, the impact on fin rays, especially the erosions exhibited in this study, may not be related to physiology, skeletal growth and developmental anomalies (Boglione et al. 2013b). Rather, fin erosions may be caused by factors such as abrasions, intraspecific aggression, nutritional deficiencies and bacterial infections (Latremouille 2003). Overall, the stress of unfavourable environments may also lead to fin erosion, as in the case of juvenile cobia Rachycentron canadum reared at suboptimal low salinities of 5 (Denson et al. 2003). The presence of eroded fins does affect mobility and results in changes to swimming patterns that may result in skeletal deformities over the long term (Divanach et al. 1996, Latremouille 2003, Boglione et al. 2013b). Ecologically, fin damage and pathological infections may make fish more vulnerable to predators potentially impacting on population size (Latremouille 2003, Hostetter et al. 2012).

In an ecological context, the results of this study indicate that $R$. holubi juveniles are resilient to hypersaline conditions, enabling them to persist in a saline-tolerant food web. Juvenile $R$. holubi depend on vegetated refugia for food and protection from piscivores (Blaber 1974a, Edworthy and Strydom 2016, Nel et al. 2017). This refuge is particularly important if mobility is reduced, due to the potential reduction in activity and fin erosion seen in this study. Conversely, the persistence of $R$. holubi populations together with other halotolerant species ensures the availability of food for halotolerant piscivores if planktivorous fish prey items decline during hypersaline conditions (Whitfield et al. 2006, Durand 2015). Thus, both the resilience to, and potential impacts of, hypersaline conditions seen in this study enable $R$. holubi to buffer food webs during hypersaline conditions. Droughts and hypersaline conditions may become more frequent and intense, especially during the dry phase of ENSO in the future (Gillanders et al. 2011, Koehn et al. 2011, James et al. 2013). This is further exacerbated by freshwater reduction practices in rivers and estuaries (Turpie et al. 2002, Adams et al. 2016). The potential synergistic effect of other factors such as increased temperature, ocean acidification, heavy metal pollution and salinity on the skeletal development of larvae and juveniles is yet unknown and may be an important aspect for study in the future. 


\section{ACKNOWLEDGEMENTS}

Research costs and bursary support was funded by the South African Research Chairs Initiative (SARChI) of the Department of Science and Technology (DST) and National Research Foundation (NRF). Any opinion, finding and conclusion or recommendation expressed in this material is that of the authors and the NRF does not accept any liability in this regard. Much appreciation goes to Mr. Mfundo Mpinga (Nelson Mandela University) for his invaluable assistance in the field and in the laboratory.

\section{REFERENCES}

Adams J.B., Cowie M., Van Niekerk L. 2016. Assessment of completed ecological water requirement studies for South African estuaries and responses to changes in freshwater inflow. Water Research Commission, WRC Report No. KV 352/15, Pretoria, $57 \mathrm{pp}$

Alarape S.A., Hussein T.O., Adetunji E.V., et al. 2015. Skeletal and other morphological abnormalities in cultured Nigerian African Catfish (Clarias gariepinus, Burchell 1822). Int. J. Fish. Aquat. Stud. 2: 20-25.

Ayed N., Faure E., Quignard J.-P., et al. 2008. Incidence of kyphosis deformities in natural population of Atherina lagunae (Trabelsi et al. 2002) from the Tunis North Lake, Tunisia. Mar. Biol. 153: 319-325. https://doi.org/10.1007/s00227-007-0813-y

Baird D., Hannekom N.M., Grindley J.R. 1986. Estuaries of the Cape. Part II: synopsis of available information on individual systems. CSIR Report No. 23, Stellenbosch, 82 pp.

Blaber S.J.M. 1973a. The ecology of juvenile Rhabdosargus holubi (Steinachner) (Teleostei: Sparidae). PhD thesis, Rhodes University, Grahamstown, $123 \mathrm{pp}$.

Blaber S.J.M. 1973b. Temperature and salinity tolerance of juvenile Rhabdosargus holubi [Steindachner (Teleostei: Sparidae)]. J. Fish Biol. 5: 593-598. https://doi.org/10.1111/j.1095-8649.1973.tb04492.x

Blaber S.J.M. 1974a. Field studies of the diet of Rhabdosargus holubi (Pisces: Teleostei: Sparidae). J. Zool. 173: 407-417. https://doi.org/10.1111/j.1469-7998.1974.tb04123.x

Blaber S.J.M. 1974b. Osmoregulation in juvenile Rhabdosargus holubi (Steindachner) (Teleostei: Sparidae). J. Fish Biol. 6: 797-800. https://doi.org/10.1111/j.1095-8649.1974.tb05122.x

Bœuf G., Payan P. 2001. How should salinity influence fish growth? Comp. Biochem. Physiol. C. Toxicol. Pharmacol. 130: 411-423. https://doi.org/10.1016/S1532-0456(01)00268-X

Boglione C., Gagliardi F., Scardi M., et al. 2001. Skeletal descriptors and quality assessment in larvae and post-larvae of wildcaught and hatchery-reared gilthead sea bream (Sparus aurata L. 1758). Aquaculture 192: 1-22. https://doi.org/10.1016/S0044-8486(00)00446-4

Boglione C., Marino G., Giganti M., et al. 2009. Skeletal anomalies in dusky grouper Epinephelus marginatus (Lowe 1834) juveniles reared with different methodologies and larval densities. Aquaculture 291: 48-60. https://doi.org/10.1016/j.aquaculture.2009.02.041

Boglione C., Gavaia P., Koumoundouros G., et al. 2013a. Skeletal anomalies in reared European fish larvae and juveniles. Part 1: normal and anomalous skeletogenic processes. Rev. Aquacult. 5: S99-S120. https://doi.org/10.1111/raq.12015

Boglione C., Gisbert E., Gavaia P., et al. 2013b. Skeletal anomalies in reared European fish larvae and juveniles. Part 2: main typologies, occurrences and causative factors. Rev. Aquac. 5: S121-S167. https://doi.org/10.1111/raq.12016

Boglione C., Pulcini D., Scardi M., et al. 2014. Skeletal anomaly monitoring in rainbow trout (Oncorhynchus mykiss, Walbaum 1792) reared under different conditions. PLoS ONE 9: e96983. https://doi.org/10.1371/journal.pone.0096983

Brauner C.J., Gonzalez R.J., Wilson J.M. 2012. Extreme environments: hypersaline, alkaline and ion-poor waters. In: McCormick S.D., Farrell A.P., Brauner C.J. (eds), Fish physiology:
Euryhaline fishes. Academic Press, Cambridge, pp. 435-476. https://doi.org/10.1016/B978-0-12-396951-4.00009-8

Claireaux G., Lagardère J.P. 1999. Influence of temperature, oxygen and salinity on the metabolism of the European sea bass. J. Sea Res. 42: 157-168. https://doi.org/10.1016/S1385-1101(99)00019-2

Deane E.E., Woo N.Y.S. 2009. Modulation of fish growth hormone levels by salinity, temperature, pollutants and aquaculture related stress: a review. Rev. Fish Biol. Fish. 19: 97-120. https://doi.org/10.1007/s11160-008-9091-0

Denson M.R., Stuart K.R., Smith T.I., et al. 2003. Effects of salinity on growth, survival, and selected hematological parameters of juvenile cobia Rachycentron canadum. J. World Aquac. Soc. 34: 496-504. https://doi.org/10.1111/j.1749-7345.2003.tb00088.x

Divanach P., Boglione C., Menu B., et al. 1996. Abnormalities in finfish mariculture: an overview of the problem, causes and solutions. International Workshop on Sea Bass and Sea Bream Culture: Problems and Prospects, Verona, pp. 45-66.

Divanach P., Papandroulakis N., Anastasiadis P., et al. 1997. Effect of water currents on the development of skeletal deformities in sea bass (Dicentrarchus labrax L.) with functional swimbladder during postlarval and nursery phase. Aquaculture 156: 145-155. https://doi.org/10.1016/S0044-8486(97)00072-0

Durand J.R. 2015. A conceptual model of the aquatic food web of the upper San Francisco Estuary. San Francisco Estuary Watershed Sci. 13: 1-37. https://doi.org/10.15447/sfews.2015v13iss3art5

Edworthy C., Strydom N.A. 2016. Habitat partitioning by juvenile fishes in a temperate estuarine nursery, South Africa. Sci. Mar. 80: $151-161$ https://doi.org/10.3989/scimar.04333.01B

Ern R., Huong D.T.T., Cong N.V., et al. 2014. Effect of salinity on oxygen consumption in fishes: a review. J. Fish Biol. 84: $1210-1220$. https://doi.org/10.1111/jfb.12330

Gillanders B.M., Elsdon T.S., Halliday I.A., et al. 2011. Potential effects of climate change on Australian estuaries and fish utilising estuaries: a review. Mar. Freshw. Res. 62: 1115-1131. https://doi.org/10.1071/MF11047

Gonzalez R.J. 2012. The physiology of hyper-salinity tolerance in teleost fish: a review. J. Comp. Physiol. B 182: 321-329. https://doi.org/10.1007/s00360-011-0624-9

Gonzalez R.J., Cooper J., Head D. 2005. Physiological responses to hyper-saline waters in sailfin mollies (Poecilia latipinna). Comp. Biochem. Physiol. A Mol. Integr. Physiol. 142: 397-403. https://doi.org/10.1016/j.cbpa.2005.08.008

Götz A., Cowley P.C. 2013. Cape stumpnose (Rhabdosargus holubi). In: Mann (ed) South African Marine Linefish Species Profiles. Oceanogr. Res. Inst. Spec. Publ. 9: 268-269, Durban.

Grant G.N., Cowley P.D., Bennett R.H., et al. 2017. Influences of selected geophysical and environmental drivers on the movement patterns of Rhabdosargus holubi in a southern African estuary. Environ. Biol. Fish. 100: 1265-1283. https://doi.org/10.1007/s10641-017-0641-y

Harrison T.D., Whitfield A.K. 2006. Temperature and salinity as primary determinants influencing the biogeography of fishes in South African estuaries. Est. Coast Shelf Sci. 66: 335-345. https://doi.org/10.1016/j.ecss.2005.09.010

Hostetter N.J., Evans A.F., Roby D.D., et al. 2012. Susceptibility of juvenile steelhead to avian predation: the influence of individual fish characteristics and river conditions. Trans. Am. Fish Soc. 141: 1586-1599. https://doi.org/10.1080/00028487.2012.716011

Izquierdo M.S., Socorro J., Roo J. 2010. Studies on the appearance of skeletal anomalies in red porgy: effect of culture intensiveness, feeding habits and nutritional quality of live preys. J. Appl. Ichthyol. 26: 320-326. https://doi.org/10.1111/j.1439-0426.2010.01429.x

James N.C., Cowley P.D., Whitfield A.K. 2007. Abundance, recruitment and residency of two sparids in an intermittently open estuary in South Africa. Afr. J. Mar. Sci. 29: 527-538. https://doi.org/10.2989/AJMS.2007.29.3.18.348

James N.C., van Niekerk L., Whitfield A.K., et al. 2013. Effects of climate change on South African estuaries and associated fish species. Clim. Res. 57: 233-248. https://doi.org/10.3354/cr01178

Kisten Y. 2018. The effects of environmental variability on the physiology and ecology of Cape stumpnose Rhabdosargus holubi (Steindachner, 1881) (Sparidae). PhD thesis, Nelson 
Mandela University, Port Elizabeth, $115 \mathrm{pp}$

Koehn J.D., Hobday A.J., Pratchett M.S., et al. 2011. Climate change and Australian marine and freshwater environments, fishes and fisheries: synthesis and options for adaptation. Mar. Freshw. Res. 62: 1148-1164.

https://doi.org/10.1071/MF11139

Kültz D. 2015. Physiological mechanisms used by fish to cope with salinity stress. J. Exp. Biol. 218: 1907-1914. https://doi.org/10.1242/jeb.118695

Latremouille D.N. 2003. Fin erosion in aquaculture and natural environments. Rev. Fish. Sci. 11: 315-335. https://doi.org/10.1080/10641260390255745

Muller C., Strydom N.A. 2017. Evidence for habitat residency and isotopic niche partitioning in a marine-estuarine-dependent species associated with mangrove habitats from the east coast of South Africa. Estuar. Coasts 40: 1642-1652. https://doi.org/10.1007/s12237-017-0240-3

Nel L., Strydom N.A., Perissinotto R., et al. 2017. Feeding ecology of Rhabdosargus holubi (family Sparidae) in multiple vegetated refugia of selected warm temperate estuaries in South Africa. Est. Coast. Shelf Sci. 197: 194-204. https://doi.org/10.1016/i.ecss.2017.08.026

Pattrick P., Strydom N.A. 2014. Recruitment of fish larvae and juveniles into two estuarine nursery areas with evidence of ebb tide use. Est. Coast Shelf. Sci. 149: 120-132. https://doi.org/10.1016/j.ecss.2014.08.003

Potter I.C., Chuwen B.M., Hoeksema S.D., et al. 2010. The concept of an estuary: A definition that incorporates systems which can become closed to the ocean and hypersaline. Est. Coast. Shelf Sci. 87: 497-500. https://doi.org/10.1016/j.ecss.2010.01.021

Potts W.M., Götz A., James N. 2015. Review of the projected impacts of climate change on coastal fishes in southern Africa. Rev. Fish Biol. Fish. 25: 603-630. https://doi.org/10.1007/s11160-015-9399-5

Strydom N.A. 2015. Patterns in larval fish diversity, abundance, and distribution in temperate South African estuaries. Estuar. Coasts 38: 268-284. https://doi.org/10.1007/s12237-014-9801-x

Strydom N.A., Whitfield A.K., Wooldridge T.H. 2003. The role of estuarine type in characterizing early stage fish assemblages in warm temperate estuaries, South Africa. Afr. Zool. 38: 29-43. https://doi.org/10.1080/15627020.2003.11657192

Swanson C. 1998. Interactive effects of salinity on metabolic rate, activity, growth and osmoregulation in the euryhaline milkfish (Chanos chanos). J. Exp. Biol. 201: 3355-3366.

Taylor W.R., Van Dyke G.C. 1985. Revised procedures for staining and clearing small fishes and other vertebrates for bone and cartilage study. Cybium 9: 107-109.

Teske P.R., Wooldridge T. 2001. A comparison of the macrobenthic faunas of permanently open and temporarily open/closed South African estuaries. Hydrobiologia 464: 227-243. https://doi.org/10.1023/A:1013995302300

Turpie J.K., Adams J.B., Joubert A. et al. 2002. Assessment of the conservation priority status of South African estuaries for use in management and water allocation. Water SA 28: 191-206. https://doi.org/10.4314/wsa.v28i2.4885

Wallace J.H., Kok H.M., Beckley L.E., et al. 1984. South African estuaries and their importance to fishes. S. Afr. J. Sci. 80: 203-207.

Whitfield A.K. 1998. Biology and ecology of fishes in South African estuaries. In: Smith J.L.B. (ed), Ichthyological Monographs 2, Institute for Ichthyology, Grahamstown, $223 \mathrm{pp}$.

Whitfield A.K., Baliwe N.G. 2013. A century of science in South African estuaries: Bibliography and review of research trends. SANCOR Occasional Report No. 7, 289 pp.

https://sancor.nrf.ac.za/Shared\%20Documents/Reports\%20 documents/SANCOR\%20Occasional\%20Report\%20No\%207. pdf

Whitfield A.K., Blaber S.J.M., Cyrus D.P. 1981. Salinity ranges of some southern African fish species occurring in estuaries. Afr. Zool. 16: 151-155. https://doi.org/10.1080/02541858.1981.11447750

Whitfield A.K., Taylor R.H., Fox C., et al. 2006. Fishes and salinities in the St Lucia estuarine system - a review. Rev. Fish Biol. Fish. 16: 1-20. https://doi.org/10.1007/s11160-006-0003-x

Whitfield A.K., Grant G.N., Bennett R.H., et al. 2017. Causes and consequences of human induced impacts on a ubiquitous estuary-dependent marine fish species. Rev. Fish Biol. Fish. 28: 19-31.

https://doi.org/10.1007/s11160-017-9499-5 